Tech Otherwise • PDC '20

\title{
How to Survive as a PD
} Researcher in a Changing World - A Personal Statement of Interest

\section{Wolmet Barendregt}

Published on: May 25, 2020

DOI: $10.21428 / 93 b 2 c 832.1450818 d$

License: Creative Commons Attribution 4.0 International License (CC-BY 4.0). 


\title{
How to Survive as a PD Researcher in Changing World - A Personal Statement of Interest
}

\author{
By Wolmet Barendregt \\ Eindhoven University of Technology \\ Contact: w.barendregt@@tue.nl
}

Climate change, depletion of natural resources and loss of biodiversity are the most serious and disruptive challenges of our time. These challenges are so big that it is hard to keep on pretending everything is fine and continue working on e.g. designing yet another educational game. Indeed, even many climate scientists are despairing by the lack of action, as for example the letters from climate scientists about how they feel, gathered by Duggan, a science communicator at Australian National University indicate (https://www.isthishowyoufeel.com/). These handwritten letters were first gathered in 2014-2015, and recently, Duggan asked them one more time about their feelings. This is not a happy reading; many of them state that they are exasperated, and some of them say that luckily, they are retiring, so they don't have to see the bad news every minute of their day. Other scientist have made the drastic choice to completely quit their research. Jem Bendell, for example, a Professor of Sustainability Leadership and Founder of the Institute for Leadership and Sustainability_(IFLAS). at the University of Cumbria (UK) has decided to start focusing on how to adapt to a collapsing world, writing in his university bio that he "has moved into a new phase of work in light of the latest climate science" (https://jembendell.com/about/).

So, if climate scientists and researchers working on sustainability don't know what to do and are switching careers, how are we in the field of Participatory Design going to deal with this? I don't have a good answer. I attempted to write a paper to the main conference in my specific sub field, Interaction Design and Children, about the need to refocus our efforts if we are serious about children's well-being. In this paper, I argued that while separate communities, such as Sustainable HCI (sHCI) and Sustainable Interaction Design (SID) have arisen within the general field of Human Computer Interaction (HCI) and Interaction Design, there is no such community within ChildComputer Interaction (CCI). This is especially surprising since today's children are likely to experience and live through the most devastating effects of the environmental 
problems. Indeed, children and youth around the world are now at the forefront of environmental activism, urging politicians to address these threats to their future. Being serious as designers about children's rights makes it almost unforgivable to ignore this aspect of CCI. However, even if we would be starting a dedicated Sustainable Child Computer Interaction community, I would still have my doubts about which direction to take. I don't think developing yet another game to teach children about recycling is going to do the trick. While many designers of persuasive technologies have traditionally shunned away from trying to change people's values because this would be 'unethical', all technology embodies values [1], and thereby influences values, be it consciously or unconsciously. Indeed, even though it is not often stated explicitly, much of the work in CCI is heavily value-driven, often focusing on children's well-being. Ironically, research has shown that while materialistic values lead to both unsustainable behaviour and lower personal and physical well-being [2], today's culture encourages children to adopt materialistic values, "through targeted messages on their cell phones and Facebook pages, and through viral marketing on the Internet and, [...], at slumber parties" [3]. So, if we cannot avoid influencing children's values through technology, and we are serious about aiming for children's well-being, which is not likely to be served by inducing materialistic values, we have to consider how we want our technologies to influence children towards more sustainable values. Value-Sensitive Design (VSD) is a way to take values of moral import into account in the design process. However, while sustainability is one of the possible values targeted in VSD, it is not evident how it can be put at the forefront without compromising other important values. Furthermore, researchers have objected that VSD does not provide a clear ethical framework to base design decisions upon [4]. While VSD is mostly concerned with stakeholder values, values-led participatory design [5], not only considers users' and stakeholders' values in the design process, but also takes into account the values that designers bring to the participatory design process. Addressing sustainability as a core value that we as designers bring into the design process for children's technologies needs a sensitive approach to deal with these value conflicts.

Knowles et al. have suggested that one way to ethically address the adoption of sustainable values in persuasive technologies is by inviting dialogue and by acknowledging that the 'desirability' of values is context-specific rather than intrinsic [6]. Although they propose that this dialogue can be created through participatory design practices, they do warn that "there is a particular framing of sustainability [...] that lends undue credence to participation, namely that sustainability is 'an emergent 
property of a conversation about desired futures'”. Instead, they propose to involve sustainability experts to determine which changes matter, and how complex factors interrelate [7]. So, my suggestion for the broader field of Participatory Design would be to really start engaging with such experts in our PD practices.

However, another more controversial idea I would like to propose, is that we as designers should be open discussions about whether a new technology should be developed at all. All technologies require the use of (non-renewable) resources, so, we constantly have to ask ourselves: does the development of this new technology justify the use of the resources needed to produce it? Of course, I am aware that this is controversial, and I have been 'accused' at times of being too political. However, I don't see how we can be a-political, just like we cannot be value-neutral. So, my interest in this workshop is to discuss with others how they feel about their work and maybe find a shared approach to create the necessary change.

\section{References}

[1] Batya Friedman, Peter H. Kahn, and Alan Borning. 2006. Value Sensitive Design and Information Systems. In Human-Computer Interaction and Management Information Systems: Foundations. M.E. Sharpe. 348-372.

[2] Tim Kasser. 2016. Materialistic Values and Goals. Annual Review of Psychology 67, 1 (2016), 489-514. https://doi.org/10.1146/annurev-psych-122414-033344 arXiv: https://doi.org/10.1146/annurev-psych-122414-033344 PMID:26273896.

[3] Tim Kasser, Tom Crompton, and Susan Linn. 2010. Children, Commercialism, and Environmental Sustainability. The Solutions Journal 1, 2 (2010), 14-17. https://www.thesolutionsjournal.com/article/ children-commercialism-andenvironmental-sustainability/

[4] Manders-Huits, N. 2011. What Values in Design? The Challenge of Incorporating Moral Values into Design. Sci Eng Ethics 17, 271-287 (2011). https://doi.org/10.1007/s11948-010-9198-2

[5] Ole Sejer Iversen, Kim Halskov \& Tuck W. Leong. 2012. Values-led participatory design, CoDesign, 8:2-3, 87-103, DOI: 10.1080/15710882.2012.672575

[6] Bran Knowles, Oliver Bates, and Maria Håkansson. 2018. This Changes Sustainable HCI. In Proceedings of the 2018 CHI Conference on Human Factors in Computing 
Systems (CHI '18).ACM, New York, NY, USA, Article 471, 12 pages.

https://doi.org $110.1145 / 3173574.3174045$

[7] Bran Knowles and Janet Davis. 2017. Is Sustainability a Special Case for Persuasion? Interacting with Computers 29,1 (2017), 58-70. https://doi.org/10.1093/ iwc/iww005 